\title{
Matadouros à imagem da cidade
}

\section{Slaughterhouses to the image of the city}

\author{
Breno Luiz T. Silva \\ Instituto Federal de Minas Gerais, Belo Horizonte, Minas Gerais / Brasil \\ breno456@gmail.com
}

Resumo: A aproximação da noção de guerra moderna com o cotidiano das cidades traz à tona a produção do heterogêneo que adentra e constitui a realidade urbana. $\mathrm{Na}$ violência que se institui na produção do espaço e migra para as relações entre as pessoas vai se constituindo uma espécie de catástrofe cotidiana. Tencionando imprecisões, faz a cidade ser estabelecida por sua parte maldita. Dizer sobre essa parte é como balbuciar no matadouro. Matadouro esse que na apropriação urbanística virou shopping.

Palavras-chave: Matadouro; heterogêneo urbano; parte maldita.

\begin{abstract}
The approximation of the notion of modern war with the quotidian of cities brings to the fore the production of the heterogeneous that enters and constitutes the urban reality. In violence that is established in the production of space and migrates to relations between people is becoming a kind of everyday catastrophe. Pretending inaccuracies, it makes the city settle for its damn part. To say about that part is like babbling in the slaughterhouse. Slaughterhouse that in urban appropriation became a shopping mall.
\end{abstract}

Keywords: Slaughterhouse; heterogeneous urban; damn part.

Recebido em: 27 de agosto de 2017.

Aprovado em: 6 de fevereiro de 2018. 


\section{Aquilo que não se quer ver, mas que está na boca do cidadão}

Nas passagens do século XIX para o XX, os matadouros foram situados a uma distância suficiente dos centros urbanos das grandes cidades de modo a garantir o abastecimento de carnes nos mercados sem dar a ver os procedimentos sangrentos, repugnantes, barulhentos e malcheirosos do abate de animais. Seguindo modelos higienistas e de produtividade eles eram instalados em áreas periféricas a alguns quilômetros dos mercados de vendas nas áreas centrais. Esse isolamento controlado das impurezas, daquilo que não deve ser sentido - e em certo sentido, sabido - por uma parcela da população, espacializa uma parte maldita ${ }^{1}$ da cidade.

É intrincado definir em termos gerais o que seja essa parte maldita, por ela não ser algo exemplar, mas se pode pensá-la enquanto parte heterogênea que fica nas margens do utilitarismo. Por ocupar um lugar marginal ela é de difícil apropriação, redução e homogeneização. Mas adentra de forma sorrateira, muitas vezes com algum consentimento, no mundo homogêneo e funcional, provocando fenômenos caóticos que desordenam e desorientam esse mundo. Ela nem sempre marca uma oposição clara, como um par antagônico e legitimador do funcionalismo e do utilitarismo que se esforçam para orientar a produção do espaço das cidades.

O excesso do utilitarismo provoca uma espécie de heterogêneo dominante, por exemplo, na instituição da guerra nos moldes modernos. A guerra é um intervalo de marcação mais do que de ruptura na catástrofe cotidiana. Catástrofe como a detecta Carl Einstein: "Eu não falo de modo sistemático simplesmente porque não posso me dar ao luxo de pensar em tais coisas [exclusivamente teóricas] e que, em meio a tudo isso, continue a se produzir a catástrofe cotidiana". ${ }^{2}$ Como se a guerra atualizasse e proporcionasse visibilidade para o cidadão daquilo que acontece ao seu redor incessantemente: a necessidade de destruir para manter o excedente. Daquilo mesmo que constitui a cidade enquanto parte maldita disseminada. A partir do século XX as cidades começam a ser destruídas no pré-guerra como nos bombardeios aéreos em Guernica na Espanha em 26 de abril e Caldeirão da Santa Cruz do Deserto na região

\footnotetext{
${ }^{1}$ Ver BATAILLE, 2013.

${ }^{2}$ Ver DIDI-HUBERMAN, 2015, p. 243.
} 
do Crato em 11 de maio de 1937. Mas também no pós-guerra como no caso da gripe espanhola assolando a população citadina brasileira a partir de setembro de $1918 .^{3}$ Parece que essa temporalidade do pré se arrasta para além de uma teleologia da guerra. Como se um campo que faz um limite com a paz improvável realizasse o próprio limite das cidades. Mas talvez o que emerge enquanto heterogêneo incapturável é a reconstrução da vida nos escombros da catástrofe, na ruína do imediato cotidiano, naquilo que não é mais uma cidade no sentido funcional, possibilitando ficcionar realidades como uma cartografia de ausências urbanas.

Nesses termos de aproximação da ausência e da ruína no imediato, seria o caso de se pensar quando os matadouros explicitam, no sentido sensível e inteligível, uma parte maldita da cidade. Talvez, mesmo na coincidência com a guerra enquanto heterogêneo instituído ou imperativo, conforme a denominação por Georges Bataille. Pensá-lo no movimento que faz da parte homogênea, funcional e útil, algo em segundo plano para uma experiência de mundo que repercuta nos modos de vida. Naquilo que, inevitavelmente, constrange a cidade na ficção de seu destino. Remexendo as vísceras sobre os papéis do planejamento urbano, pressente-se nos matadouros uma violência que retorna à cidade. Violência que antecipa a ruína espacial provocada pela guerra, assim como o arruinamento do sujeito nos processos do combate-abate. Pressente-se em seus restos aquilo mais ordinário que corresponde a "forma" espacial da crônica policial violenta e criminosa e ao suplício na cidade, um "objeto" espaço-temporal movediço capaz de provocar uma experiência no fora de si a quem se dispor a ele e retornar desestabilizando a ordem instituída.

O matadouro de La Vilette foi construído entre 1859 e 1867 numa região de 39 hectares a cerca de cinco quilômetros do centro de Paris. Distância e organização em conformidade com o urbanismo higienista

${ }^{3}$ Em $O$ mez da grippe de Valêncio Xavier aproxima a gripe Espanhola com a Primeira Guerra Mundial. A primeira imagem do livro é o rosto daquele que padece, da próxima vítima ou de um garoto propaganda para xaropes. O ano é 1918 e a gripe espanhola paira no ar. A moléstia ataca a população. Moléstia que pode ser a gripe, a guerra, o crime, o capitalismo ou a "a paz interrompida". A montagem estabelecida apresenta o cotidiano, como uma atualização de jornal, mas que deixa sentir o fundo catastrófico que o constitui. Fundo catastrófico que ao aproximar o cotidiano da guerra leva a linguagem no limite da sua própria incomunicabilidade, de sua falibilidade diante da experiência radical e sua limitação na anestesia do dia a dia. Ver XAVIER, 1998. 
preconizado por Rambuteau. Em 1929, Eli Lotar faz uma incursão nesse território então afastado da efervescência citadina e realiza a série fotográfica Matadouro de La Vilette, ${ }^{4}$ publicada na revista Documents $\mathrm{n}^{\circ}$ 6 (1929), acrescida do verbete Matadouro por Georges Bataille. Ambos tornam visível e estranhamente legível essa parte desconsiderada da cidade pela burguesia metropolitana, "as boas criaturas", como debocha Bataille:

Realmente, nos dias de hoje o matadouro é posto de quarentena como um barco que transporta a cólera. Ora, as vítimas desta maldição, não são os carniceiros nem os animais mas as boas criaturas que chegam ao ponto de não poderem suportar a sua asseada fealdade, com efeito uma fealdade que responde a uma necessidade malsã de limpeza, de biliosa pequenez e tédio: a maldição (que só aterroriza quem a profere) leva-as a vegetar o mais longe possível dos matadouros, a exilar-se por correcção num mundo amorfo onde já nada existe de horrível e onde elas se encontram reduzidas, ao sofrer a indelével obsessão da ignomínia, a comer queijo. (BATAILLE, 1994, p. 102).

Essa parte maldita faz o sujeito "asseado e entediado" estremecer, atualizando uma dimensão obscura e violenta para ele: aquela da matança dos animais que, conforme Bataille, indicia o sacrifício coincidindo com a heterogeneidade. Por um lado resta fugir, se encapsulando no mundo homogêneo, fazendo as crianças acreditarem que a carne vem do saco plástico da marca tal, que o sangue escorre longe desse mundo e que logo ali é aonde é preciso a todo custo evitar ir. O fato inevitável que se afronta a essa obscenidade é a de que a "carne fresca" retorna à cidade na produção dos “espetáculos" cotidianos, seja nas vedetes midiáticas, seja na violência instituída, abraçada na cultura do pânico e naquilo mesmo que entra goela abaixo nos mais de vinte mil assassinatos assistidos nos primeiros quinze anos de vida via programas de televisão. Cultura avessa à natureza, à crueza e, por mais estranho que pareça, à crueldade como elemento constituinte do heterogêneo.

Por outro lado, o que seria adentrar nesse lugar do sacrifício, na produção do heterogêneo - e sabe-se lá o que é desejar isso - e se lançar

\footnotetext{
${ }^{4}$ Ver imagens do Matadouro de La Vilette de Eli Lotar. Disponível em: <http://40. media.tumblr.com/tumblr_lbmoueDwPD1qzse0lo1_1280.jpg>.
} 
a ele com todo o risco de se perder de uma realidade social. Risco como o que atingiu o Coronel $\mathrm{Kurtz}^{5}$ na beira de qualquer racionalidade que, na montagem cinematográfica no filme Apocalypse Now, sobrepõe a sua morte degolado com o sacrifício de um búfalo asiático, enquanto meditava sobre o horror da guerra. Risco de se perder a cabeça...

\section{Indefinições vaporosas}

Alfred Döblin evoca a noção de sacrifício em seu romance Berlim, Alexanderplatz, publicado em 1928, um ano antes do verbete Matadouro de Bataille e das fotos de Lotar. A personagem de seu livro Franz Biberkopf saído da prisão e decidido a mudar de vida vai se deparando com uma cidade que não vai mudar para melhorá-lo, o que torna seu sacrifício inevitável. ${ }^{6}$ Aqui o sacrifício assume a imagem de algo irreparável, de uma derrota existencial e de uma entrega que irrompe da condição adversa nos guetos das cidades e que atinge até o corpo da personagem, imagem concentrada no braço mutilado da personagem ao final do livro.

${ }^{5} \mathrm{O}$ Coronel Kurtz aparentemente enlouqueceu, abandonou os comandos do exército americano durante a Guerra do Vietnã e passou a comandar a sua própria tropa de montanheses dentro do neutro Camboja como um semideus. Perseguido como inimigo de guerra acaba morto enquanto seus seguidores matam cerimonialmente um búfaloasiático, o capitão Willard, responsável pela missão entra na câmara do Coronel que está fazendo uma gravação em fita, e o ataca com um machete. Mortalmente ferido no chão, Kurtz sussurra suas palavras finais antes de morrer. Willard descobre obras datilografadas dos escritos do Coronel e os leva antes de sair. Kurtz interpretado por Marlon Brandon é uma personagem do filme Apocalypse Now (1979) dirigido por Francis Ford Copolla e roteirizado por Jonh Millus a partir do romance Heart of Darkness de Joseph Conrad. Veja o filme em: <https://www.youtube.com/watch?v=I_su2L5fg0s>. ${ }^{6}$ Como reflete Döblin: "Pero fuera nada habia cambiado y el mismo habia seguido siendo el que era. Como podía producirse un nuevo resultado? Evidentemente, solo si uno de los dos resultaba destruido, Berlin o Franz Biberkopf. Y como Berlin siguio siendo el que era, al penado se le ocurrio cambiar. El tema interno es, por lo tanto, que hay que sacrificarse, ofrecerse a si mismo en sacrificio. Y pronto aparecen en el libro, para el que sepa leer, los temas del sacrificio: el bíblico Abraham debe sacrificar a su único hijo al Dios supremo, se nos lleva al matadero del este de la ciudad y presenciamos la muerte de las bestias". EPILOGO A UNA NUEVA EDICION (1955) Alfred Döblin Hochenschwand (Selva Negra), 31 de julio de 1955. In: DÖBLIN, 2007, p. 23 
Berlim era uma cidade que passava por uma crise econômica agravada pela hiper-inlfação decorrente da derrota alemã na primeira Guerra Mundial, e com uma instabilidade política que solapava a democracia enquanto crescia os discursos nacionalistas e anti-semitas. Uma cidade que anunciava em seus espaços marginais a guerra que viria. Nesses espaços de bairros pobres super adensados e de vida apática ditada pela luta cotidiana pela sobrevivência, habitavam as classes proletárias, os desempregados e toda sorte de marginais, prostitutas e "joãos sem braços". Em A crise do romance. Sobre Alexanderplatz, de Döblin (1930) Walter Benjamin descreve a Alexanderplatz e seu entorno como um bairro comercial que sofre os impactos da modernização, escancarando as "vísceras da cidade" e convive com a marginalidade atraída pelo comércio. ${ }^{7}$ Atrás da Alexanderplatz, ao leste, ficavam os bairros miseráveis e um pouco mais acima, a noroeste, ficava o matadouro de Berlim.

No Livro Quatro de Berlim Alexanderplatz, Döblin descreve o matadouro de Berlim enquanto imagem do lugar do sacrifício e, por conseguinte, da aparição do heterogêneo por excelência na cidade. ${ }^{8}$ A descrição começa com a citação do Eclesiastes 3, 19: "O destino do homem é o mesmo do animal; o mesmo destino os aguarda. Assim como morre um, também morre o outro". Essa epígrafe denota a irredutibilidade da morte enquanto marca a condição comum ao homem e aos outros animais, numa aproximação entre ambos que é continuada e reforçada adiante no texto. Na descrição do matadouro segue uma série de estatísticas sobre a área, as quantidades dos rebanhos, os quilos

\footnotetext{
7 “O que é, em Berlim, Alexanderplatz? É o lugar onde se dão, nos últimos dois anos, as transformações mais violentas, onde guindastes e escavadeiras trabalham incessantemente, onde o solo treme com o impacto dessas máquinas, com as colunas de automóveis e com o rugido dos trens subterrâneos, onde se escancaram, mais profundamente que em qualquer outro lugar, as vísceras da grande cidade, onde se abrem à luz do dia os pátios dos fundos em torno da praça Georgenkirch, e onde se preservaram mais silenciosamente que em outras partes da cidade, nos labirintos em torno da Marsiliusstrasse (onde as secretárias da Policia dos Estrangeiros estão alojadas em cortiços) e em torno da Kaiserstrasse (onde as prostitutas praticam, à noite, suas rondas imemoriais), remanescentes intactos da última década do século passado. Não é um bairro industrial, e sim comercial, habitado pela pequena burguesia. No meio de tudo isso, o negativo sociológico desse meio: os marginais, reforçados pelos contingentes de desempregados". BENJAMIN, 1987a, p. 57-58.

${ }^{8}$ Ver DÖBLIN, 2007. p. 89-95.
} 
de carne produzidos, baseados em vários documentos da época, como o Memorando sobre a inauguração do Grande Mercado de Carne de Berlim de outubro de 1925. Também são descritos os prédios e seus funcionamentos a partir de observações e considerações pessoais do autor. Alguns ambientes são mostrados em funcionamento com certa ambiguidade, envoltos por vapores. Nada pode ser visto nesse vapor espesso que os encobre, nesse "banho turco para porcos", os óculos estão embaçados, os homens talvez estejam nus, e se ouve somente os ruídos, golpes, gritos, e estalidos de ferramentas caídas. Atrás desses espaços se encontra o lugar do sacrifício dos animais, anunciados por solavancos, gritos e gemidos mais altos. Há caldeiras e tanques de onde saem o vapor que inunda os outros ambientes. ${ }^{9}$

Os gritos e vapores dizem de um impensado, daquilo que não consegue ser descrito com clareza. Essas descrições assumem formas narrativas fenomênicas de vapores e gemidos enquanto estados extratores preparam o leitor para a descrição do sacrifício de um grande touro branco que coincide com aquilo que o não saber evidencia. Nesse trecho não há descrições técnicas nem vapores e grunhidos. O touro entra e parece que ele se entrega ao sacrifício que vem pela mão do homem, por pancadas que o atordoam, fazem-no estremecer e estrebuchar. No entanto, o sangue ainda corre em suas veias. Na sequência, o touro é golpeado com uma faca cravada na sua garganta e o sangue escorre, viscoso, escuro e quente: "Logo toda a alegre festa abandonará a casa".

Essa descrição corresponde ao estado do êxtase, ainda no limite da morte, em que o sangue jorra - já não é o vapor - rumo ao irredutível, o heterogêneo mesmo, que é quando o touro tomba e não mais se levanta. Quando: “(...) se acabou tudo, arrastado pelo vento, um buraco vazio, trevas, chega agora uma nova visão de mundo. Até aqui, de repente

\footnotetext{
9 "Um empurrão na porta, ela tem molas, balança para dentro e para fora. Argh, que fumacê! O que estão fazendo. E você fica no meio do vapor como num banho, talvez os porcos estejam tomando banho turco. Anda-se a esmo, você não enxerga por onde está caminhando, os óculos ficam embaçados, talvez a gente esteja nu, o reumatismo sai pelos poros como suor, conhaque só não ajuda, os tamancos castanholando. Não se enxerga nada, o vapor é denso demais. Mas estes guinchos, resfolegos, estalidos, gritos dos homens, instrumentos caindo, tampas batendo. Aqui, em algum lugar, devem estar os porcos, vindos da ala lateral. Este vapor denso e branco. (...) Lá atrás devem ficar os locais de abate, lá se ouvem palmadas, batidas, guinchos, roncos, grunhidos". DÖBLIN, 2009, p. 153-154.
} 
aparece um senhor que comprou uma casa, vão abrir uma rua, a conjuntura é melhor, ele vai demoli-la". ${ }^{10} \mathrm{O}$ touro resta como uma casa demolida. Como uma ruína no imediato, heterogêneo visto de vislumbre no fluxo, vidência da morte que resta nesta estranha aproximação de coincidência acelerada da cidade feita sobre especulações imobiliárias. Se fosse possível alguma lição, bastaria agora inverter a ordem do Eclesiastes: "o destino do animal é o mesmo do homem". Morrer pelas mãos do homem, numa entrega por ignorância e apatia destinadas de antemão. Parece que é assim mesmo que acontece entre os homens, "uma carnificina bem iluminada"11 que é pressentida nos abates da cidade. Enquanto ruínas, os matadouros não passam de rastros, ambientes vaporosos, quentes, onde o sangue escorre, fétidos, algo próximo do imaginário infernal, daquilo que não quer ser sentido pelo mundo homogêneo, mas que não deixam de assombrá-lo. Maldição que faz retornar o vapor fétido para a cidade seja no esgoto estourado, seja sobre a carne em putrefação rodeadas de moscas e na defecação que o sujeito mira antes de dar a descarga sanitária. Gesto de despedida que revela a defecação como a excreção enquanto ponta final da cadeia "produtiva" dos consumidores dirigidos.

Nas narrações contemporâneas de Bataille, de Lotar e de Döblin, os espaços do matadouro, as ruínas e o cotidiano miserável nas cidades adquirem características sensíveis, psíquicas e fenomênicas, que desfuncionalizam tais situações e as retornam como "documentos" do resto do heterogêneo. Isso, porque entre eles emerge em velocidade um movimento de alteração que os desapropriam num movimento semelhante àquele da História do Olho ${ }^{12}$ de Bataille onde numa sequência desordenada e caótica, o olho vira grito que vira sangue que vira sêmen que vira urina que vira leite que vira cú que vira estrelas que vira olho que vira vapor que vira grito que vira morte do touro que vira testículo do touro que vira vísceras que vira olho que vira sol que vira...Tais "documentos" são signos imediatos da alteração. Mas esses "documentos" dos restos do heterogêneo, por si, tendem a incitar a experiência aos que se deparam com eles? Eles atualizam a maldição que assombra o mundo homogêneo?

\footnotetext{
${ }^{10}$ Cf. DÖBLIN, 2007, p. 91-92.

${ }^{11}$ DÖBLIN, 2007, p. 92.

${ }^{12}$ Ver BATAILLE, 2003. Ver FOUCAULT, 2001. v.3.
} 
$\mathrm{Na}$ falta do excesso, o grande touro branco vira o churrasco da família no fim de semana enquanto "as boas criaturas" assistem programas de tevê com dançarinas "carnes frescas" ao fundo. A carne embalada em plástico e comprada no supermercado é desvirilizada e serve para aumentar as estatísticas de obesidade e colesterol alto dos habitantes das cidades. Aquilo que atiça a vista e embrulha o estomago na dança repetitiva das vedetes em cenários coloridos da tevê proporcionando o mal-estar do final do fim de semana. São excessos estáticos, paralíticos. Enquanto isso, o sangue passa longe, escorre nas periferias marginalizadas mas adentra de forma visual nos noticiários sensacionalistas ameaçando as centralidades. E os matadouros na realidade de algumas cidades brasileiras aderiram a outros nomes, como "desova", em mais uma subversão do trecho do Eclesiastes: "o destino do homem é o mesmo do peixe devorado pelo outro". ${ }^{13}$

\section{A cidade maldita}

Simões Filho cidade na Região Metropolitana de Salvador (BA) foi considerada pelo Mapa da Violência de 2012 a cidade mais violenta do Brasil com uma taxa de 146,4 homicídios para cada 100 mil habitantes. Ela possui uma enorme área industrial que fazia parte do CIA (Centro Industrial de Aratu) abandonada desde a década de 1980. Com cerca de $220 \mathrm{mil} \mathrm{m}^{2}$, esse local foi convertido em local para "desova" de cadáveres vindos principalmente de homicídios ocorridos nas periferias de Salvador e das cidades próximas. Na Via Periférica I que dá a cesso a área, os galpões abandonados são utilizados para assassinatos e vários veículos roubados são abandonados e queimados ao longo da estrada. As carcaças metálicas anunciam as humanas. Espécie de matadouro às avessas que também recaí nos noticiários da imprensa sensacionalista.

Basta um recorte das manchetes, que sempre vêm acompanhadas de imagens de mulheres semi-nuas e escritas em caixa-alta, nas últimas semanas do jornal Super Notícia, publicado e distribuído na Região Metropolitana de Belo Horizonte, para se ver tudo aquilo que não quer ser visto nem sabido e que irrompe no cotidiano das cidades que

13 "De facto a dignidade do espaço está muitíssimo bem estabelecida e associada às das estrelas, ao ponto de ser incongruente afirmarmos que ele pode transformar-se num peixe que devora outro peixe". Ver o Verbete Espaço In: BATAILLE, 1994, p. 97. 
parecem menos violentas: "MORRE QUEIMADO MAS REVELA O ALGOZ"; "MÃE E MADASTRA INDICIADAS POR CRUELDADE"; "ARROZ RECHEADO COM MACONHA"; "IRMÃO INGRATO PAGA A DÍVIDA COM TIRO; "MOSNTRO CONFESSA O CRIME BÁRBARO". ${ }^{14}$ Assim como as estatísticas de Simões filho, o que o jornal Super coloca em supra é uma violência instituída que associa a mulher semi-nua, essa "carne fresca" a uma notícia de um crime atroz, mas que também causa um desconfortável e estranho prazer ao leitor. A parte da violência instituída é uma variante do controle social, que não é novidade desde que existe sociedade. Ela assume formas no espectro do mundo homogêneo contemporâneo no que se pode chamar de cultura do pânico. Mas sobre a estranha atração dessas manchetes e de suas imagens, disso é mais difícil de dizer, pois parece que não é possível reduzir isso no jogo da alienação por associação, redundância e da manipulação subliminar. Talvez o que escape daí, inclusive do prazer imediato enquanto finalidade, é um movimento alterante quando o próprio pânico estoura da anestesia e produz algum relance heterogêneo.

Nesse matadouro às avessas alastrado cidades afora, exacerbando a violência instituída, opera uma desvitalização programada onde todos os espaços das cidades estão mais ou menos vigiados como potenciais locais de um crime numa atualidade da assertiva de Benjamin ao olhar para as fotografias da Paris de início do séc. XX feitas por Atget. ${ }^{15}$ Todos os passantes são suspeitos de antemão, são criminosos potenciais aos olhos do Estado e consumidores potenciais aos olhos das Empresas. Parece que todos são suspeitos do crime inaugural: do crime contra a propriedade, essa forma de pilhagem legitimada e instituída; do crime em não participar do consumo dirigido; do crime de não se subordinar às formas imperativas de comunicação.

Retomando a manchete "IRMÃO INGRATO PAGA A DÍVIDA COM TIRO", pode-se extrair daí uma recaída bíblica que mitifica a vida cotidiana. A morte do irmão, do semelhante, é narrada no mito dos irmãos Caim e Abel. Caim, que no hebraico significa lança, é a figura no antigo

\footnotetext{
${ }^{14}$ Algumas manchetes do jornal Super Notícias dos meses de maio e junho de 2016. Disponível em: <http://www.otempo.com.br/super-noticia/>.

15 "Com justiça escreveu-se dele que fotografou as ruas como quem fotografa o local de um crime. Também esse local é deserto. É fotografado pelos indícios que contêm". Ver BENJAMIN, 1987b, p. 174.
} 
testamento do primeiro homicida que após matar seu irmão Abel parte em fuga para o leste do Éden onde funda uma cidade com o nome de seu filho Enoc. Miticamente ele lança a humanidade no crime contra o semelhante e funda o espaço para isso: a cidade. É esse seu legado que faz de cada pessoa um criminoso, da cidade uma construção criminosa, e de seus espaços locais de crimes. Contra esse legado se instituem as leis e suas variantes de controle. Mas também o que se indicia ai é um crime contra a semelhança, a idealidade que faz do homem a semelhança de deus e, por conseguinte, contra a idealidade que quer fazer da cidade o melhor lugar ou o habitat "natural" para a humanidade.

A cidade pode ser vista como um território hostil. Um território que cega quem se atreve a vê-la desnuda pela fresta. A cidade enquanto núcleo centralizador e útil é contraposta ao que toma parte nela de modo excêntrico, desviando do domínio homogêneo, exorbitando os olhos ela privilegia a parte maldita. Aparecem nela os moribundos se divertindo na rua, as práticas escusas e inclassificáveis da vida na noite da cegueira peremptória que esgarça os domínios do próprio. Suas espacialidades no jogo de construção de realidades se aproximam da noção de informe $e^{16}$ Bataille, como espacialidades em alteração e inclassificáveis, que não se definem a priori e adquirem suas formas-moventes singularmente considerando as temporalidades no devir provocado pelo fora de si.

A cidade maldita emerge parcialmente expropriada e imprópria. Expropriada porque ela se conecta a partir da suspensão temporária da propriedade e consiste na contestação cultural como forma de arranjo de sociabilidades. Imprópria, pois não se sustenta geopoliticamente, mas num conjunto de espacialidades heterogêneas e nos processos de subjetivação coletiva em suas experimentações. Esses fragmentos conectados da cidade consistem por espacialidades em transe delineando situações temporárias que subvertem a configuração da produção do espaço urbano e sua axiomática fundamental que naturaliza a noção de propriedade seja ela privada ou pública. Co-existe alguma espécie de cidade - se é que ainda se pode sustentar essa identidade - onde

${ }^{16}$ No verbete Informe, Bataille reitera as características de impropriedade e de desclassificação de uma integridade prévia do espaço, escreve: “informe não é só um adjectivo com determinado sentido mas um termo que serve para desclassificar e em geral exige que todas as coisas tenham a sua forma" ou seja, que tenha a sua forma singular num dado momento experimentado. Ver BATAILLE, 1994, p. 99. 
parcialmente a noção de propriedade esteja colocada em xeque a partir da subversão dos usos dos espaços e em processos de subjetivações coletivas em ocupações insubordinadas, subversivas e imprevisíveis.

Cidade em dispêndio. Aparecem, inevitavelmente, outras formas de viver e pensar as cidades que não são necessariamente melhores ou piores que as instituídas. Trata-se basicamente de uma transgressão de perspectiva sobre os modos de pensar e realizar a vida. De uma abertura privilegiada ao heterogêneo que, no caso em questão, é um limite ao pensamento sobre a cidade, emergindo um impensado que repentinamente salta a um saber jovial que não é somente um ato filosófico ou científico, mas também abertura à desordem e, no limite, ao próprio caos avançando sobre a produção de outras "formas" de conhecimento. Pode-se, assim, imaginar outra cidade a partir da revisão do paradigma de dominância da homogeneidade? Talvez, na visão de uma cidade sacrificial à imagem do matadouro, cujos maus presságios se antevê pelos cantos da cidade contemporânea.

\section{Balbucios no matadouro}

Mostrar o crime em cada espaço da cidade e em cada cidadão começa a indiciar alguma política. Se, como afirma Bataille, "a humanidade só se reúne por um ditador ou por uma tragédia", ${ }^{17}$ a cidade enquanto esse espaço de agrupamento só pode ser um espaço de controle sobre uma tragédia que não cessa de se anunciar: como um local de controle do crime da propriedade, mais do que do crime contra a propriedade. Antes desta detecção assumir as brumas teóricas condizente a uma política obscura - manifesta no matadouro, na pedra e no sangue -, numa esquina mal iluminada na periferia da cidade, alguém blefa: "o coito é a paródia do crime". 18 "Seu monstro, seu criminoso", retruca Benjamin que a essa altura, pela gravidade da voz, já reconhecera Bataille ${ }^{19}$

17 “La vida exige que hombres se reúnan, y los hombres no se reúnen más que gracias a un jefe o una tragedia". BATAILLE, 2005, p. 130.

${ }^{18}$ BATAILLE, 2007, p. 46.

${ }^{19}$ Não se poderia deixar de fazer referência aqui ao episódio citado por Agambem, através da reminiscência de Klossowski, de uma cisma intelectual entre Bataille e Benjamin. Em um debate no Collège de sociologie em fins dos anos 30, Benjamin acusa Bataille de fascista. A esse episódio acrescente-se o fragmento da correspondência com Adorno em que Benjamin insinua uma necessidade de aliança com Bataille e àquele 
na penumbra. Diante de elogios mútuos, ambos riem um riso solto e abrem uma conversa sob a sombra que, aos poucos, fazia confundir as suas vozes. O riso é comunicação do êxtase em Bataille e em Benjamin remete a expressão "mais selvagem (o esgar da dentadura)". ${ }^{20} \mathrm{~A}$ partir desse enlace, a comunicação entre eles começa violenta e distanciada.

O silêncio da noite perturbado não facilitava o entendimento sobre o que conversavam. Mas parece que Benjamin defendia no extremo que a pedra, numa ancestralidade mineral, atualiza o horror da experiência que eleva o matadouro à instituição cultural desde sua materialidade. Enquanto que para Bataille bastava uma cusparada imediata, um jorro de sangue bilioso e o vislumbre do horror está dado naquela matéria insalubre mas que atiçava alguma vitalidade. Horror que não deixa de ser "aprovação da vida até na morte". ${ }^{21}$ Sangue do instante da morte de um grande touro branco. Por saltos, a distância entre seus pontos de vista - seus furos nas vistas - converge para a comunicação num sentido trágico como possibilidade de alteração e contestação culturais.

Abandonando o bloco de notas, sussurra imprecisamente Benjamin: ${ }^{22}$ sem sutilezas psicológicas, e no esquecimento de si a comunicação se infiltra na espessura da caixa craniana, talvez, naquilo que o homem tenha de mais próximo à noção de mineral. E continua com voz um pouco mais clara e escrita: "A morte é a sanção de tudo o que o narrador pode contar. É da morte que ele deriva sua autoridade. Em outras palavras: suas histórias remetem à história natural." ${ }^{23}$ Essa

em que Bataille torna-se o seu depositário, escondendo os manuscritos de Benjamin na Bibliothèque Nationale- inclusive suas Passagens - durante a Segunda Guerra. Existe ai um balbucio entre os dois, uma tensão entre dois pensamentos que buscam colocar em crise, fraturar ou mesmo dilacerar certa condição cultural de sua época, condição essa atualizada, se considerada amparada na transcendência e na subordinação, noutras formas de fascismo menos objetivas em nossos dias. Na base do rumor, Bataille e Benjamin são interlocutores, ao menos em "comunidade de amizade". Ver AGAMBEN, 2005, p. 91-94. E ver LONITZ, 1999, p. 276

${ }^{20}$ BENJAMIN, apud DIDI-HUBERMAN, 2010, p. 157.

${ }^{21}$ BATAILLE, 2004, p. 19.

22 "Quanto maior a naturalidade com que o narrador renuncia às sutilezas psicológicas, mais facilmente a história se gravará na memória do ouvinte (...)" e "Quanto mais o ouvinte se esquece de si mesmo, mais profundamente se grava nele o que é ouvido". Ver BENJAMIN, 1987c. p.204-205.

${ }^{23}$ BENJAMIN, 1987c, p. 208. 
vidência desesperada enunciada, sem qualquer expectativa que não seja indiciar o fóssil na passagem, produzia uma atmosfera "mística" entre eles, abria a conversa para formas de pensamento não racionais e muito menos científicos. E logo concordaram - com a mesma concordância dos risos - quando Benjamin concluía que nas profundezas inanimadas o narrador se torna anônimo e "anterior a qualquer escrita" 24 enquanto Bataille, quase que simultaneamente, resmungava: "escrevo para apagar meu nome".

As pedras do velho muro em que se recostavam se tornara a partir daí elemento de reflexão de ambos. Decantados de suas interioridades olhavam para aquele muro como indício da catástrofe vinda de fora e assombrando tudo o que é humano. Vislumbravam "uma profecia natural do mundo mineral e inanimado dirigida ao mundo histórico". ${ }^{25}$ Petrificados, sob efeito do assombro, sucumbiam na fragilidade da ideia de si, e essas estátuas dramáticas - feito seus livros - vão fissurando e perdendo a expressão frágil de horror para se decomporem em pó. O muro, a pedra e a partícula de pó indiciavam, assim, tanto uma memória que nos faz esquecer de nós mesmos enquanto sujeitos, quanto a abertura para outra possibilidade "cultural" comunicada por uma espécie de barbárie positiva. Num sentido rápido, a barbárie é o sintoma do que vem, do desconhecido, do outro que é a atualização da expressão da diferença. Um terreno vago se abria, meio devastado, nele crescia desordenadamente uma vegetação em que mais tarde alguns buscarão seus remédios, outros vão dar vazão às suas perversões e, mais adiante, erguerão suas edificações sobre ruínas especuladas.

Enquanto caminhavam à noite nessa parte desconhecível da cidade, já bastante foras de si, tateavam aquele espaço informe, e além das vegetações que brotavam pelas frestas, em alguns trechos eles sentiram escorrer um líquido viscoso. Líquido que se confundia com a saliva que a essa altura engasgava a fala de ambos. Só se "entendiam" agora na medida em que aceleravam o transe em que adentravam. A ponto de irromper mais um riso seco seguido de um grito, ainda que esses sons não ecoem pelas ruas. E, sem querer, resta algo de premonitório sobre o socius como uma catástrofe inumana antevista numa poça de sangue.

${ }^{24}$ BENJAMIN, 1987c, p. 219.

${ }^{25}$ BENJAMIN, 1987c, p. 219. 
Bataille tentaria elucidar o acontecido tempo depois dobrando a experiência na noção de narrativa: "a narrativa que revela as possibilidades da vida, não atrai necessariamente, mas incita um momento de fúria, sem o qual seu autor estaria cego para essas possibilidades excessivas". ${ }^{26}$ Diante das possibilidades da vida reveladas, ele intuía que a estranha conversa entre ambos atraia o movimento da desordem, do desmanche excêntrico para fazer aparecer uma experiência coletiva, talvez num sentido benjaminiano, e a marcha da história nas crises de quem quer que seja, nas feridas sangrentas expostas.

Nessa experiência ou ligação mística entre eles - como insistia Benjamin em denominar a situação - ambos, lançados ao fora de si, foram acometidos por vidências que assombravam cada qual com uma intensidade singular na seguinte imagem partilhada: uma pedra que coincidia com as fotos de crimes e se liquefaziam numa mistura abjeta mergulhadas no chão. Uma "tragédia impessoal" encarnava no excesso perturbador da imagem. Água mole em pedra dura, excessos e o presságio de um crime. Quando deram por si e olharam ao redor, perceberam que estavam num matadouro. Aos poucos se definiam duas abordagens desse encontro, uma que parte do sujeito e outra do contexto sociocultural. Um discorria sobre o "não-saber" e o outro sobre o "som bárbaro" quando, sem querer, coincidiam num balbucio de contestação cultural no momento do abate do touro que cortou o silêncio da noite.

\section{O matadouro que virou shopping}

Agora já não é mais possível mirar o matadouro sem qualquer afeto, não haveria mais como escondê-lo ou torná-lo obsceno. Resta mostrá-lo. No primeiro plano se avista uma multidão de urubus na rua, ao fundo um galpão coroado por urubus em fila no seu cimo, alguns figurantes humanos encostados na parede do prédio próximos a entrada ficavam quase que camuflados. Trata-se de uma fotografia do matadouro de Belo Horizonte na déc. de 60 do séc. XX. ${ }^{27} \mathrm{O}$ matadouro modelo de Belo Horizonte foi inaugurado no dia 17 de outubro de 1937. No final da década de 1930, estava sendo negociado o aumento dos abatimentos

\footnotetext{
${ }^{26}$ BATAILLE, 1986, p. 9.

${ }^{27}$ Fotografia do acervo do Arquivo Público Municipal de Belo Horizonte. Referência da Imagem: BRMGAPCBH//AB.10.01.00-038-17755.
} 
diários, que era de 100 rezes e 20 porcos, quantidade insuficiente para as necessidades da população crescente da capital. Assim, ele foi construído no mesmo empenho que os já mencionados, para suprir as necessidades de abastecimento e problemas de higiene e, como tal, se situava na Vila Operária, no bairro São Paulo, distante cerca de cinco quilômetros do centro da cidade.

$\mathrm{Na}$ área destinada ao matadouro de Belo Horizonte, cidade originalmente planejada, hoje fica um shopping. Estranha substituição, mas que indicia um sobre-apagamento, uma nova obscenidade no espaço que evita a relação com o fora e que institui o mercadoria a qualquer custo. Henri Miller em suas memórias dos anos 30 do séc. XX identificava os recém inventados supermercados como os novos pastos contemporâneos. Como um pasto ainda mais alargado, os shoppings são locais de consumo dirigido nos quais as pessoas são impelidas a comprar por estímulos sensoriais, pela ausência de iluminação natural e de relógios, pela profusão de aromas e de músicas, e pela configuração espacial labiríntica que desorienta a saída ao passo que direcionam às lojas comerciais como refúgios que preparam para o abate. Neles ocorre o famoso Gruen Transfert ${ }^{28}$ nome dado em homenagem ao inventor dos Shoppings na década de 40 do séc. XX ao efeito de convulsão psíquica, próximo da picnolepsia, espécie de dislexia da percepção que acomete os consumidores mais normais nos shoppings. Entre os sintomas, destacamse os passos lentos e as bocas abertas, com algumas variações, como lamber os beiços, morder os lábios, roer as unhas e os olhos arregalados. Os excessos dos estímulos provocam um transe às avessas onde no fora de si - que passa a ser a evidência extrema do sujeito que só quer "acelerar" e não experimentar - ocorre a indução ao consumo dirigido.

Talvez, esse efeito seja produto da recaída de uma técnica sacrificial que sirva ao controle social como aqueles que se infligiam aos corpos humanos nas cerimônias Astecas e faziam rolar cadáveres destroçados escada abaixo dos templos piramidais. Mas trata-se de uma técnica acrescida de outros artifícios, como aquele que substitui a faca nos modernos processos de abate pelo uso de eletro-choque que, em tese, diminuem o sofrimento do animal e eliminam os jorros de sangue oriundos da degolação estrebuchada. Assim como estas, por sua vez,

${ }^{28}$ Ver FERREIRA. Disponível em: <http://cinegnose.blogspot.com.br/2013/04/aarquitetura-subliminar-de-victor.html $>$. 
serviriam bem às pesquisas de neuromarketing empenhadas no consumo dirigido. Sobre tantas recaídas, vez ou outra ainda sobrevoam pelos shoppings urubus atordoados em busca de outros tipos de carniças. Urubus cujos cantos provocam um "som bárbaro" contrapostos à música ambiente.

\section{Referências}

AGAMBEN, Giorgio. Bataille e o paradoxo da soberania. Tradução de Nilcéia Valdati. Outra Travessia. Revista de Literatura, Ilha de Santa Catarina, n. 5: A exceção e o excesso. Agamben \& Bataille, p. 91-94, 2. sem. 2005,

BATAILLE, Georges. A parte maldita precedida de a noção de dispêndio. Tradução de Júlio Castañon Guimarães. Belo Horizonte: Autêntica, 2013.

BATAILLE, Georges. O ânus solar (e outros textos do sol). Tradução de Aníbal Fernandes. Lisboa: Assírio \& Alvim, 2007.

BATAILLE, Georges. Crónica nietzscheana. In: BATAILLE, Georges; CAILLOIS, Roger; KLOSSOWSKI, Pierre. Acéphale. Tradução de Margarita Martínez. Buenos Aires: Caja negra, 2005.

BATAILlE, Georges. O erotismo. Tradução de Cláudia Fares. São Paulo: Arx, 2004.

BATAILLE, Georges. História do olho. Tradução e prefácio Eliane Robert Moraes. São Paulo: Cosac \& Naif, 2003.

BATAILLE, Georges. A mutilação sacrificial e a orelha cortada de Van Gogh. Tradução de Carlos Valente. Lisboa: Hiena Editora, 1994.

BATAILlE, Georges. O azul do céu. Tradução de Maria Lucia Machado. São Paulo: Brasiliense, 1986.

BATAILLE, Georges; CAILLOIS, Roger; KLOSSOWSKI, Pierre. Acéphale. Tradução de Margarita Martínez. Buenos Aires: Caja negra, 2005.

BENJAMIN, Walter. A crise do romance. Sobre Berlim Alexanderplatz, de Döblin. In: . Obras escolhidas. v. 1. Magia e técnica, arte e política. Ensaios sobre literatura e história da cultura. Tradução de Sérgio Paulo Rouanet. Prefácio de Jeanne Marie Gagnebin. São Paulo: Brasiliense, 1987a. 
BENJAMIN, Walter. A obra de arte na era da reprodutibilidade técnica. In: . Obras escolhidas. v. 1. Magia e técnica, arte e política. Ensaios sobre literatura e história da cultura. Tradução de Sérgio Paulo Rouanet. São Paulo: Brasiliense, 1987b.

BENJAMIN, Walter. O narrador. Considerações sobre a obra de Nikolai Leskov. In: . Obras escolhidas. v. 1. Magia e técnica, arte e política. Ensaios sobre literatura e história da cultura. Tradução de Sérgio Paulo Rouanet. São Paulo: Brasiliense, 1987c.

DIDI-HUBERMAN, Georges. O que vemos, o que nos olha. Tradução de Paulo Neves. São Paulo: Ed.34, 2010.

DIDI-HUBERMAN, Georges. Diante do tempo. História da arte e anacronismo das imagens. Belo Horizonte: Ed. UFMG, 2015.

DÖBLIN, Alfred. Berlin Alexanderplatz. Tradução de Miguel Saenz. Madrid: Ediciones Catedra, 2007.

DÖBLIN, Alfred. Berlin Alexanderplatz. Tradução Irene Aron. São Paulo: Martins Fontes, 2009.

FERREIRA, Wilson R. A arquitetura subliminar de Victor Gruen no documentário "Gruen Effect". Disponível em: <http://cinegnose. blogspot.com.br/2013/04/a-arquitetura-subliminar-de-victor.html >.

FOUCAULT, Michel. Elogio à transgressão. In: MOTTA, Manoel Barros da (Org.). Ditos e escritos. Estética: literatura e pintura, música e cinema. Rio de Janeiro: Forense Universitária, 2001. v.3.

LONITZ, Henri (Ed.). Theodor W Adorno and Walter Benjamin. The complete correspondence, 1928-1940. Cambridge, Mass.: Harvard University Press, 1999.

XAVIER, Valêncio. O mez da grippee outros livros. São Paulo: Companhia das Letras. 1998. 